Andrea Vuković
Svetlana Mihićc $^{2}$
Ljiljana Miletić $^{3}$
Radmila Čurčić $^{4}$
JEL: M1, M14, D12

DOI: $10.5937 /$ industrija44-12689

UDC: 005.35:334.7(497.11)

659.4

Original Scientific Paper

\title{
Corporate Social Responsibility as a part of Corporate Public Relations in Serbia ${ }^{5}$
}

\author{
Article history: \\ Received: 12 August 2016 \\ Sent for revision: 9 September 2016 \\ Received in revised form: 11 November 2016 \\ Accepted: 12 November 2016 \\ Available online: 30 December 2016
}

\begin{abstract}
Besides the media, the web presentations of the companies are one of the possible and widely applied means for communication of corporate social responsibility (CSR). For efficient CSR communication, good planning of the massages that will be presented to the public is of particular importance. It is additionally emphasized in the countries in the transition period where the social environment is burdened with numerous problems that result in preformed public mistrust towards companies. The extent and the results of public cognition of the company and creation of its identity and image are highly dependent from content of the web presentation but also of the manner of presentation and positioning of specific contents. Application of adequate slogans, can also highly contribute to the visibility of specific information. In order to review the way in which companies in Serbia present their CSR motives and activities, the web pages of leading companies in Serbia from the agro-business, public and financial sectors were analyzed and the practice of presentation of CSR to the public was reviewed. The similarities and differences in approach to CSR communication among analyzed sectors are outlined in the research results.
\end{abstract}

Keywords: public relations, corporate social responsibility, communication, web presentations

\footnotetext{
${ }^{1}$ Economics institute, Belgrade, Serbia, andrea.vukovic@ecinst.org.rs

${ }^{2}$ University Educins, Sr.Kamenica, Serbia, Faculty for business economics

${ }^{3}$ University Educins, Sr.Kamenica, Serbia, Faculty for project and innovation management

${ }^{4}$ University „Union-NikolaTesla“, Serbia, Faculty for industrial business management, Belgrade

5 The paper presents the results of a study conducted as a part of the projects: III46001, funded by the Ministry of Education, Science and Technological Development, Republic of Serbia.
} 
Vuković A. et al.: Corporate Social Responsibility as a part of Corporate Public ...

\title{
Korporativna društvena odgovornost kao element korporativnih odnosa sa javnošću vodećih kompanija u Srbiji
}

\begin{abstract}
Apstrakt: Web prezentacije kompanija su pored sredstava javnog informisanja jedan od mogućih i široko korišćenih načina komuniciranja KDO. Kad je u pitanju komunikacija korporativne društvene odgovornosti dobro planiranje poruka koje se šalju javnosti ima poseban značaj, koji naročito dolazi do izražaja u zemljama u tranziciji u kojima je društveno okruženje opterećeno brojnim problemima koji za rezultata imaju unapred formirano nepoverenje javnosti prema kompanijama. Pored sadržaja prikazanog na web stranama kompanija, način prezentacije i pozicioniranje pojedinih sadržaja u velikom meri utiče na meru $i$ rezultate spoznaje javnosti o kompaniji $i$ izgradnju njenog identiteta $i$ imdža, a upotreba adekvatnih slogana, u velikoj meri doprinosi pristupačnosti informacija. Kako bi se sagledalo kako kompanije u Srbiji na web stranicama prezentuju svoje motive $i$ aktivnosti KDO analizirane su web stanice vodećih kompanija u Srbiji iz sektora agrobiznisa, javnog i finansijskog sektora i sagledana je praksa predstavljanja KDO javnosti. Sagledane su sličnosti i razlike koje u pristupu komunikaciji $K D O$ na web stranicama postoje među analiziranim sektorima.
\end{abstract}

Ključne reči: odnosi sa javnošću, korporativna društvena odgovornost, komunikacija, web stranice

\section{Introduction}

The basic philosophy of public relations is very simple - the goals can be achieved much easier with the support and understanding of the public, than when the public is opposed or indifferent. Public relations, regardless if they are used in the spheres of business life, in social relations, in political arena, for humanitarian purposes or in other situations, are characterized with the same essence of the goals. They can be described with several keywords: reputation, perception, credibility, trust, unity and mutual understanding based on a true and comprehensive flow of the information. In corporations, public relations have the task, not only to contribute to the success and profitability of the company, but also to position the corporation as "a good citizen and a social leader" with the care of social responsibility as a significant factor of its competitiveness (Black, 1993).

Corporate social responsibility (CSR) is the support for good image. Social responsibility is a set of relations that company maintains with all its stakeholders, including customers, employees, local community, shareholders, government, suppliers and competitors. Undeniably, through the creation of 
Vuković A. et al.: Corporate Social Responsibility as a part of Corporate Public ...

the identity powerful tools for adding of the value to the company, its shareholders and other stakeholders, can be set in motion. The fact that the company which succeeds in development of its image as "good corporate citizen" will also benefit with better valuation of its products at the market and improvement of its position at the stock markets, has been widely discussed and proven. Good corporate reputation results in the establishment of mutual trust with consumers and consequently stimulates the sales and even the prices (Lukić, 2010).

Professionals in the field of corporate public relations are aware of so-called RACE formula that implies planned approach to public relations in four stages included in the acronym: R-research; A-analysis; C-communication and Eevaluation. This approach involves inseparable stages in every model of planning and implementation of public relations programs (Cutlip, et al. 2000).

The governments, activists and media became skilled in blaming the companies for social consequences of their activities. Numerous organizations rank companies in respect to their CSR activities. In spite of sometimes-questionable methodologies, these rankings attract significant attention in the public. As a result, corporate social responsibility has significant and unavoidable priority for the business leaders in the countries worldwide. Successful corporations need healthy society. Education, healthcare and equal opportunities are of essential importance for productive workforce. Safe production and working conditions can attract customers, but also reduce internal costs. Efficient utilization of soil, water, energy and other natural resources contributes to the business productivity. The companies operate in a competitive context that affects significantly their ability to implement the strategies, especially in long terms. Social conditions represent the core part of this context. For these reasons, the CSR strategy should be placed ahead of the best business practices by every company. In this way the position is obtained that enables creation of advantages in comparison to competitors in a manner that reduces costs and/or contributes to better fulfillment of customers' needs (Porter i Kramer, 2007).

Relations with employees, financial relations, relations with local communities, crisis communications, political relations, public relations in the service of the public interest, consumers' education are all the responsibilities allocated to the PR-activities (Mirosavljević, 2008).

In addition to profit making, companies are also engaged in supporting of the society and the environment. According to Elkington (1997) organizational performances are evaluated on the basis of economic prosperity, social justice and the quality of the environment. They are considered by the management, employees, investors and consumers with the aim to assess the policies and strategies of the companies (Blazovich i Smith, 2011; Cronin et al., 2010; Makni et al., 2009). 
Vuković A. et al.: Corporate Social Responsibility as a part of Corporate Public ...

Socially responsible thinking and orientation is proven to be useful. Companies striving to support the humankind and the environment are associated with better financial results, increased creativity and innovation, and encouragement of their competitive position in the market (Kassinis \& Vafeas, 2006; King \& Lenox, 2002). Academic research and market research point out that stakeholders and citizens are willing to reward good corporate image (Porter \& Kramer, 2007; Smith et al., 2010).

However, numerous studies point out that the public awareness of the CSR activities undertaken by the companies is usually at quite low level, even among the stakeholders (Bhattacharya et al., 2008; Du et al.., 2007). According to these studies, numerous consumers are not aware of the fact the majority of the companies is nowadays involved in some kind of activity that supports humankind and the environment. If the consumers and the investors are mainly uninformed, that means that the companies did not communicate their CSR activities successfully. If the company wants to attain any use at the market based on its CSR activities, it has to communicate efficiently its policies and activities to all stakeholders. Striving to improve communications, many companies experiment with the utilizations of slogans in order to emphasize their goals and activities related to CSR (Verboven, 2011).

One of the possible ways for CSR communication, beside the media are obviously the web pages of the companies. Accessibility and visibility of information related to CSR can be significant factor that can contribute to improvement or deterioration of consumers' loyalty to the brand or its commitment for the particular product / service (Ellonen et al., 2010).

From the viewpoint of the consumers' perception or his commitment to particular brand, product or service, the promotion of CSR is characterized with significant influence. Among numerous market opportunities existing nowadays, the consumers have the luxury to choose where to spend their money. Why should they not buy form the companies that contribute to the society, unlike the ones that simply force the sales and profits? Having this in mind, the consumers pay attention to the non-business activities of the companies. In order to increase their public acceptance, companies have to provide the information about their socially responsible activities (De Baker i Den Hond, 2008).

Having in mind the pro-active nature of socially responsible business, corporate public relations can play significant role in establishment of understanding between the corporation and the public. This role is accomplished through the increase of the awareness of the need of ethical functioning, implementation of CSR programs and communication of CSR results in public. In this sense, CSR is no longer just the part of the public 
Vuković A. et al.: Corporate Social Responsibility as a part of Corporate Public ...

relation strategy, but the public relations are becoming an integral part of CSR as ethical operation (Skoko \& Mihovilović, 2014).

Based on that the attitude that the CSR concept endangers the concept of profit maximization is exceeded and it is considered that these two concepts complement each other (Santini, 2007). During past years, more and more arguments and proofs that CSR is a profitable business strategy are presented and CSR confirms its commercial value (Tench \& Yeomans, 2009).

Clearly defined relation between CSR and public relation is hard to be found in current literature, but the opinion of Sommerville (2007), that there is a twoway communication among stakeholders that develops the sense of trust and mutual respect, can be adopted. From one side the results of socially responsible business are communicated towards the stakeholders, but at the other side, their demands are listened by the company. For example, public relations with local community can initiate public debate, support democratic decision-making or strengthen the activities of the community (Gregory, 2009). In this way, public relations serve the public interest.

In the process of transition, as emphasized by Lukić (2010) the relations of companies with the public are of utmost importance for achievement of mutual understanding among groups of people or institutions that are not rarely confronted. Because of unpopular but often also illegal practices practiced by the companies in the transition period, genuine distrust already exists in public, based either on unfavorable experiences or on incomplete information about the companies (Lukić, 2010). Through the nurturing of CSR, but even more by appropriate communication of these activities to the public, companies can greatly contribute to the overcoming of such attitudes and development of identity and image of the companies as responsible members of the social community (Ivanović-Đukić, 2011).

However, unlike the practice in developed countries, public relations in the transition countries are in many cases the consequence of crisis, urgent situations and problems, rather than planned and targeted positioning of the company in the eyes of public. In communication of corporate social responsibility, good planning of the massages that will be launched into public is of particular importance. Reaction of the public to the massages launched by the companies in relation to their social responsibility can often oppose the logical expectations. For example, as proven by Kim (2014) emphasizing of philanthropic motives by the companies with bad reputation, can result in additional negative consequences for the image of the company in public.

As stated by Ivanović-Đukić (2011) the companies in Serbia to not give the strategic importance to the CSR, ant the activities of the majority of the companies are reduced to the sponsorships and donations, with utilization of CSR mainly in marketing purposes. 
Vuković A. et al.: Corporate Social Responsibility as a part of Corporate Public ...

One of widely available communication channels that can be used by the companies in order to manage public relations without external interferences are undoubtedly companies' web pages (Ćurčić et al., 2016). Beside the content presented on companies' web pages, the way in which certain contents of the web pages are presented and their position in the web presentations can highly influence the extent and results of public cognition about the company and development of its identity and image. Utilization of adequate slogans can highly contribute to the accessibility of the information. However, as emphasized by Ćurčić et al. (2016), consumers' expectations and the contents of web presentations related to socially responsible operation of the companies are, in the majority of cases, not aligned. Regarding the utilization of slogans for communication of CSR, significant differences, but also some similarities, have been identified among the companies from the processing, services and trade sectors (Smith i Alexander, 2013).

As stated by Maignan and Ralston (2002) the way in which the companies present their CSR activities in the web pages differs to high extent also among the developed countries. Based on that, even more expressed differences might be expected in relation to the countries in the transition, like Serbia.

The aim of present research is to review the frequency, intensity and way in which CSR is communicated by the leading companies in Serbia from the agro-business, public and financial sector and to identify the differences in CSR communication among analyzed sectors.

\section{Materials and methods}

The study included 65 leading companies from Serbia, with 20 companies from financial and public sector and 25 companies from the sector of agribusiness. The selection of the companies from the public and agrobusiness sector was performed by random selection of the companies from the list of 500 companies with the highest annual turnover in 2013 in Serbia (http://top500.nin.co.rs). The selection of 20 banks as the representatives of the financial sector was also performed by random selection from the list of all banks registered and operating in Serbia. For the companies selected in described way the content of web pages was analyzed starting from their home pages.

In order to obtain consistent data, based on preliminary review of web pages from all three analyzed sectors the data coding scheme was developed. The review of the web pages included the following aspects: 
Vuković A. et al.: Corporate Social Responsibility as a part of Corporate Public ...

- Existence and position of the information related to CSR in the web pages. Companies were coded as the ones that emphasized their CSR with a slogan, the ones that positioned CSR in the main menu, the ones that positioned CSR under any of the main menu options, the ones that mentioned CSR activities in the web presentation but at the place which was difficultly approachable or hidden and the ones that did not mention CSR in their pages at all.

- Based on the way in which CSR was presented the companies were coded as the ones that provided the whole CSR program and/or report at the web pages, the ones that provided detailed description of the CSR activities, the ones that provided only the list of conducted CSR activities, the ones that mentioned CSR only in declarative manner and the ones that did not provide any information about CSR.

- Regarding the field of CSR activities for the main field of CSR including society, environment, suppliers, employees and consumers related activities the companies were categorized as the ones for which observed field is dominant, the ones that have existing activities related to observed field of CSR and the ones that do not present the activities related to the observed CSR field. In the same way was conducted the coding and categorization of the companies in respect to the motives emphasized by the companies to be involved in CSR activities including strategic, stakeholder and value motives.

Pearson's Chi square method was used in order to perform the statistical analysis of formed database and to identify existence of statistically significant differences among analyzed sectors.

Besides the coded data the slogans used by the companies and the titles used to identify CSR by the companies were systematized and analyzed.

\section{Results and discussion}

Position of CSR, the way of its presentation, frequency of presentation of involvement in certain fields of CSR and presented CSR motives will be discussed based on collected information from the web pages of the leading companies in Serbia.

Position of CSR related information in web presentation of analyzed companies is presented in Figure 1A. Obtained results confirm the fact emphasized already by Ivanović-Đukić (2011) and Ćurčić et al. (2016) that the majority of the companies in Serbia, even among the leading ones do not apply the CSR concept or at least do not communicate these activities to the public. In even $48 \%$ of analyzed web pages, no CSR related information is 
Vuković A. et al.: Corporate Social Responsibility as a part of Corporate Public ...

presented. Opposite to this fact utilization of CSR related slogans as the efficient way for dragging of public attention to CSR activities of the company (Verboven, 2011) is present quite rarely (1\%). CSR activities of the companies are mainly positioned either in the main menu accessible from the company's home page $(12 \%)$, or CSR is one of the item present under the main menu titles $(31 \%)$, mainly under the title under which the basic information about the company is presented (about us or similar). Quite rarely the information about CSR activities of the companies is positioned in a way where they can difficultly be found ( $8 \%)$. Based on presented findings it can be concluded that either the leading Serbian companies do not care about CSR concept at all, or if they are conscious of the importance of CSR, they present it in their web pages in clearly visible and accessible manner.

Regarding the content of the CSR presentations, the situation is quite different (Figure 1B). Only $4 \%$ of analyzed companies present their CSR activities in a form of complete annual report. Additional $5 \%$ companies present CSR activities in documented way with names, places, dates and/or numbers enabling real introspection in their CSR activities. However, majority of the companies either provide only the list of CSR activities (26\%) or in declarative way without data about conducted or planned activities (17\%). Based on the findings it can be concluded that the web presentations of leading Serbian companies will rarely assure the visitor of the web page of company's CSR activities and contribute in this way to development of company's image as a responsible society member.

Figure 1 - Position and form of CSR communication at web pages of the leading companies in Serbia

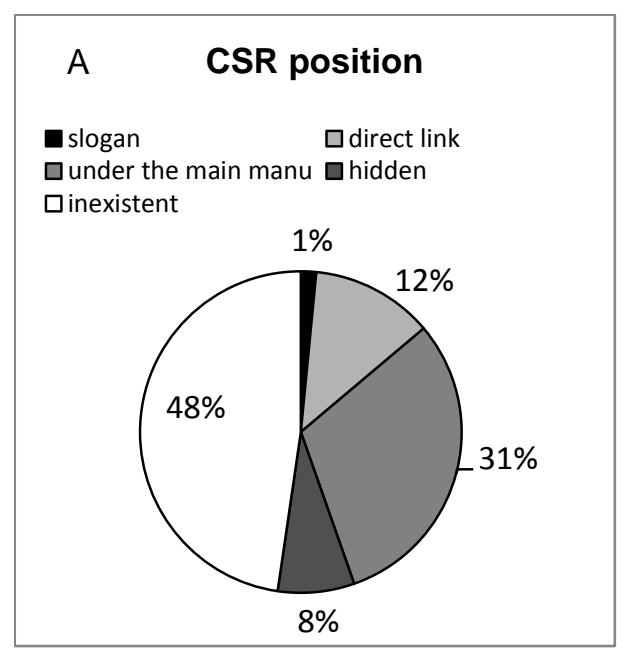

\section{B CSR presentation form}

- complete report $\quad$ documented activities 口listed activities amentioned 口inexitent

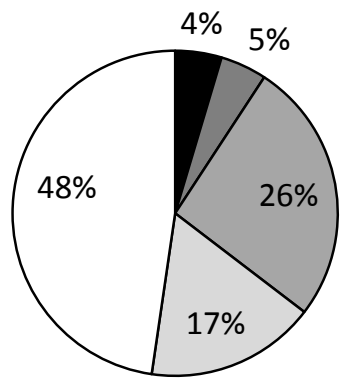

Industrija, Vol.44, No.4, 2016 
Vuković A. et al.: Corporate Social Responsibility as a part of Corporate Public ...

Analysis by the sectors included in the research (Table 1) points out that that the inexistence of any information about CSR at company's web page characterizes mainly the public sector $(60 \%)$. Majority of web pages presenting CSR in a manner that causes difficulties to be found is also from public sector. Companies from financial and agro-business sector present mainly their CSR activities either under the main menu or under one of the main menu titles (over $40 \%$ in both sectors). Only small number of the companies from agro-business sector uses the slogans that drag attention of the visitor directly to socially responsible behavior of the company.

Table 1 - Differences in position of CSR related information at the web pages among the companies from agro-business, financial and public sector in Serbia $(p=0.4254)^{*}$

\begin{tabular}{|l|c|c|c|}
\hline \multirow{2}{*}{ Position of CSR related information } & \multicolumn{3}{|c|}{ Sector } \\
\cline { 2 - 4 } & Agro-business & Public & Financial \\
\hline Slogan at the home page, \% & 7,7 & 0,0 & 0,0 \\
\hline Option in the main menu, \% & 11,5 & 10,0 & 15,0 \\
\hline $\begin{array}{l}\text { Under one of the main menu } \\
\text { options, \% }\end{array}$ & 30,8 & 15,0 & 45,0 \\
\hline $\begin{array}{l}\text { Existence of indirectly } \\
\text { approachable information, \% }\end{array}$ & 3,8 & 15,0 & 5,0 \\
\hline $\begin{array}{l}\text { Inexistence of any CSR related } \\
\text { information, \% }\end{array}$ & 46,2 & 60,0 & 35,0 \\
\hline
\end{tabular}

${ }^{*}$ For $p<0,05$ statistically significant differences exist among analyzed sectors

Complete CSR reports confirming that the company included CSR as a strategic element is presented also only by the companies from financial $(10 \%)$ and agro-business (3.8\%) sector in which additional $7.7 \%$ of the companies present the detailed description of CSR activities. The phenomenon that CSR is presented in non-documented manner is equally present among companies from all three analyzed sectors.

Table 2 - Differences in a way of presentation of CSR at the web pages among the companies from agro-business, financial and public sector in Serbia $\left(p=0.4642^{*}\right)$

\begin{tabular}{|l|c|c|c|}
\hline \multirow{2}{*}{ The way of CSR presentation } & \multicolumn{2}{|c|}{ Sector } \\
\cline { 2 - 4 } & $\begin{array}{c}\text { Agro- } \\
\text { business }\end{array}$ & Public & Financial \\
\hline Complete CSR report, \% & 3,8 & 0,0 & 10,0 \\
\hline Detailed description of CSR activities, \% & 7,7 & 5,3 & 0,0 \\
\hline List of CSR activities, \% & 26,9 & 15,8 & 40,0 \\
\hline CSR mentioned in declarative way, \% & 15,4 & 15,8 & 15,0 \\
\hline Inexistence of CSR information, \% & 46,2 & 63,2 & 35,0 \\
\hline
\end{tabular}

* For $p<0.05$ statistically significant differences exist among analyzed sectors 
Vuković A. et al.: Corporate Social Responsibility as a part of Corporate Public ...

However, the differences among the position and the content of CSR presentation in the web pages for three analyzed sectors are not statistically significant ( $p>>0.05)$.

Based on the information presented at the web pages CSR activities of the leading Serbian companies (Figure 2) are directed mainly to the socially responsible treatment of environment and society, while the stakeholders including employees, customers and especially business partners like suppliers or business customers are treated by quite smaller number of companies. Only for CSR activities related to the environment the share of companies presenting these activities as dominant is significant.

Figure 2-Presentation of CSR activities related to different CSR field by the leading companies in Serbia

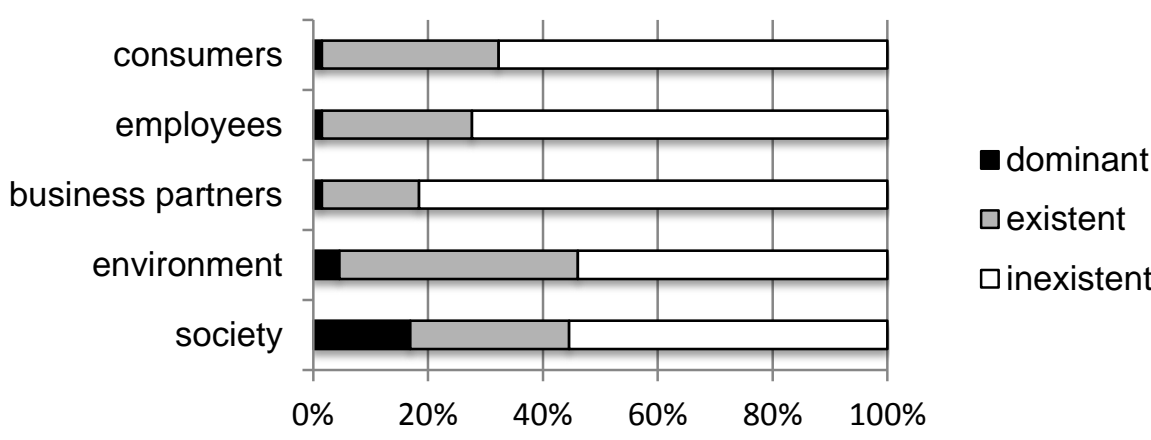

Analysis of presented CSR activities by sectors (Table 3 ) confirms that CSR related to environment is equally present among all three analyzed sectors with inexistence of statistically significant difference among the sectors ( $p>>0,05)$. The differences among analyzed sectors do not also exist in the case of CSR directed to the care of employees. Regardless of the sector, this part of social responsibility is never emphasized as dominant. For other CSR field the differences are also not proven statistically significant but based on quite low $p$ values for Pearson Chi square test it can be concluded that some differences might exist. For example, dominant position of the care for the society, mainly expressed through donations and sponsorships is characteristic for financial and agro-business sector and never dominant in the public sector. Public sector is also characterized with complete inexistence of presentation of any CSR activity related to business partners i.e. suppliers. In the financial sector presentation of CSR activities related to customers is present more often than in other two sectors. 
Vuković A. et al.: Corporate Social Responsibility as a part of Corporate Public ...

Table 3 - Differences in field in which CSR activities are presented at the web pages among the companies from agro-business, financial and public sector in Serbia

\begin{tabular}{|l|r|r|r|r|r|}
\hline & $\begin{array}{c}\text { Society } \\
(p=0,0940)^{*}\end{array}$ & $\begin{array}{c}\text { Environment } \\
(p=0,5775)^{*}\end{array}$ & $\begin{array}{c}\text { Suppliers } \\
(p=0,0538)^{*}\end{array}$ & $\begin{array}{c}\text { Employees } \\
(p=0,3610)^{*}\end{array}$ & $\begin{array}{r}\text { Consumers } \\
(p=0,0661)^{*}\end{array}$ \\
\hline \multicolumn{7}{|c|}{ Agro-business sector } \\
\hline Dominant & 20,0 & 8,0 & 0,0 & 4,0 & 0,0 \\
\hline Existent & 28,0 & 40,0 & 20,0 & 20,0 & 28,0 \\
\hline Inexistent & 52,0 & 52,0 & 80,0 & 76,0 & 72,0 \\
\hline \multicolumn{7}{|c|}{ Public sector } \\
\hline Dominant & 0,0 & 0,0 & 0,0 & 0,0 & 0,0 \\
\hline Existent & 25,0 & 35,0 & 0,0 & 20,0 & 15,0 \\
\hline Inexistent & 75,0 & 65,0 & 100,0 & 80,0 & 85,0 \\
\hline & \multicolumn{7}{|c|}{ Financial sector } \\
\hline Dominant & 30,0 & 5,0 & 5,0 & 0,0 & 5,0 \\
\hline Existent & 30,0 & 50,0 & 30,0 & 40,0 & 50,0 \\
\hline Inexistent & 40,0 & 45,0 & 65,0 & 60,0 & 45,0 \\
\hline
\end{tabular}

* For $\mathrm{p}<0,05$ statistically significant differences exist among analyzed sectors

Based on the statement that the motives for CSR are more important for the public than the very activities of CSR (Ellen et al., 2006), present study included also the review of the motives for CSR stated by the companies (Figure 3). Value motives related to the readiness of the company to support the society without any direct return to the company are present for almost all companies presenting their social responsibility at the web pages, but this motive is never dominant. Dominant position is reserved mainly for the strategic motives related to improvement of company's performance based on CSR, while CSR motivated by the stakeholders is rarely dominant.

Figure 3 - Presented motives for CSR by the leading companies in Serbia

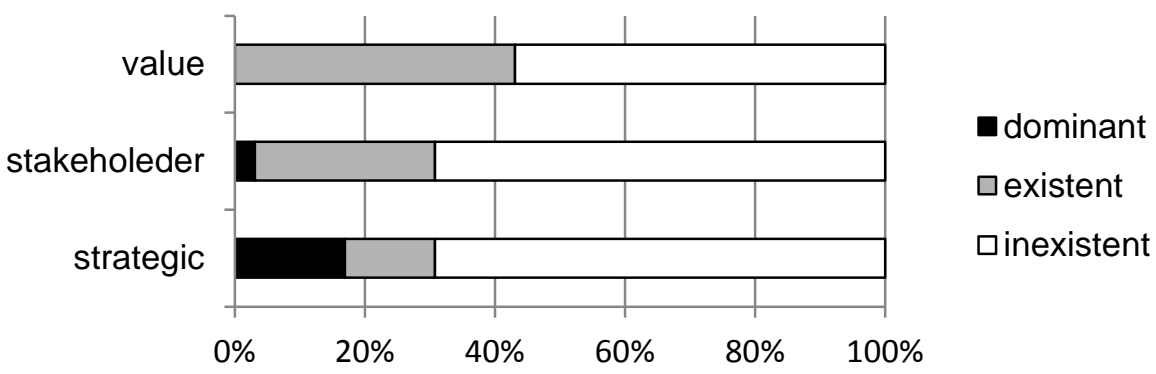

In the case of presentation of motives for CSR at the web pages, there are statistically significant differences among analyzed sectors for value and 
Vuković A. et al.: Corporate Social Responsibility as a part of Corporate Public ...

stakeholder motives. These differences are related mainly to almost completely inexistent stakeholder motives in public sector and more often emphasized value motives in the financial sector.

Table 4 - Differences in motives for emphasized at the web pages among the companies from agro-business, financial and public sector in Serbia

\begin{tabular}{|l|c|c|c|}
\hline \multirow{2}{*}{ Position } & $\begin{array}{c}\text { Stated CSR motives } \\
(\mathrm{p}=0,0603)^{*}\end{array}$ & $\begin{array}{c}\text { Stakeholder } \\
\text { motives } \\
(\mathrm{p}=0,0350)^{*}\end{array}$ & $\begin{array}{c}\text { Value motives } \\
(\mathrm{p}=0,0354)^{*}\end{array}$ \\
\hline \multicolumn{4}{|c|}{ Agro-business sector } \\
\hline Dominant & 16,0 & 0,0 & 0,0 \\
\hline Existent & 12,0 & 32,0 & 40,0 \\
\hline Inexistent & 72,0 & 68,0 & 60,0 \\
\hline \multicolumn{5}{|c|}{ Public sector } \\
\hline Dominant & 0,0 & 0,0 & 0,0 \\
\hline Existent & 20,0 & 10,0 & 75,0 \\
\hline Inexistent & 80,0 & 90,0 & 0,0 \\
\hline \multicolumn{4}{|c|}{ Financial sector } \\
\hline Dominant & 35,0 & 10,0 & 65,0 \\
\hline Existent & 10,0 & 40,0 & 35,0 \\
\hline Inexistent & 55,0 & 50,0 & 75,0 \\
\hline
\end{tabular}

${ }^{*}$ For $p<0,05$ statistically significant differences exist among analyzed sectors

Figure 4-Frequency of terms used in CSR communication in the web pages of the leading companies in Serbia

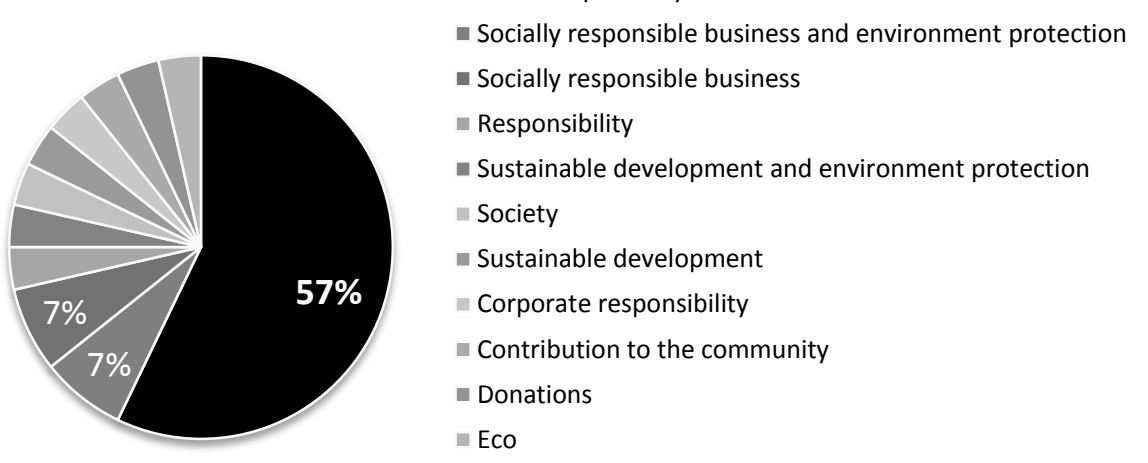

Finally based on conducted review of the web pages of the leading companies from agro-business, financial and public sector in Serbia the terms 
Vuković A. et al.: Corporate Social Responsibility as a part of Corporate Public ...

used to denote CSR activities of the companies were systematized (Figure 4). Although the terms social responsibility and socially responsible business are used in $2 / 3$ cases, it has to be noted that there is a variety of terms used to present socially responsible behavior of the company. Used terms are mainly derived from the dominant field of CSR activities like environment or donations, or widened to the concept of sustainable development.

\section{Conclusions}

The leading Serbian companies, either do not care about CSR concept at all, or if they are conscious of the importance of CSR, they present it in their web pages in clearly visible and accessible manner. Inexistence of any information about CSR at company's web page characterizes mainly the public sector $(60 \%)$. CSR activities of the companies are mainly presented in no documented manner and thus cannot assure the visitor of the web page of company's CSR activities nor they can contribute in this way to development of company's image as a responsible society member. The phenomenon that CSR is presented in non-documented manner is equally present among companies from all three analyzed sectors. However, the differences among the position and the content of CSR presentation in the web pages for three analyzed sectors are not statistically significant.

Activities of the leading Serbian companies (Figure 2) are directed mainly to the socially responsible treatment of environment and society, while the stakeholders including employees, customers and especially business partners like suppliers or business customers are treated by quite smaller number of companies. There are no statistically significant differences in respect of CSR activities among financial, agro-business and public sector. However, there are indications that public sector is rarely involved in any activities related to the society, and never emphasizes CSR activities related to the supply chain members. The financial sector more often emphasizes CSR activities related to customers.

Value or philanthropic motives for CSR exist in almost all web presentations in which CSR is presented, but strategic motives are the ones that are the most often emphasized as dominant. In the case of presentation of motives for CSR at the web pages, there are statistically significant differences among analyzed sectors for value and stakeholder motives.

Based on conducted study and presented results, it could be concluded that the presentation of CSR activities at the web pages by Serbian companies should be improved in order to contribute to creation of the image of a socially responsible member of the society for the companies. 
Vuković A. et al.: Corporate Social Responsibility as a part of Corporate Public ...

\section{References}

Bhattacharya, C.B., Sen, S., \& Korshchun, D. (2008). Using corporate social responsibility to win the war for talent. Sloan Management Review, 49, 37-44.

Black, S. (1993). The Essentials of Public relations. Kogan Page Limited.

Blazovich, J., \& Smith, L.M. (2011). Ethical corporate citizenship: Does it pay?, Research on Professional Responsibility and Ethics in Accounting.

Cronin, , J.J., , Smith, J.S., Gleim, M.R., Ramirez, E., \& Martinez, J.D. (2010). Green marketing strategies: An examination of stakeholders and the opportunities they present. Journal of the Academy of Marketing Science, 39, 158-174.

Cutlip, S.M., Center, A.H., \& Broon, G.M. (2000). Effective Public Relations, 8th ed. Prentice Hall..

Ćurčić, R., Miletić, (., \& Bjegović, M. (2016). Contrasting of CSR strategies selfpresentations and consumers expectations in Serbia. Industrija, 44(1), 151-166.

de Bakker, F.G.A., \& den Hond, F. (2008). Activists' Influence Tactics and Corporate Policies. Business Communication Quarterly, 71(1), 107-111. doi:10.1177/1080569907313381

Du, S., Bhattacharya, C.B., \& Sen, S. (2007). Reaping relationship rewards from corporate social responsibility: The role of competitive positioning. International Journal of Research in Marketing, 24, 224-241.

Elkington, J. (1997). Socially responsible organizational buying: Environmental concern as a noneconomic buying criterion. Journal of Marketing, 58(3), 1-19.

Ellen, P., Webb, D., \& Mohr, L. (2006). Building corporate associations: Consumer attributions for corporate socially responsible programs. Journal of the Academy of Marketing Science, 34, 147-157.

Ellonen, H.K., Tarkiainen, A., \& Kuivalainen, O. (2010). The effect of website usage and virtual community participation on brand relationships. International Journal of Internet Marketing and Advertising, 6(1), 85. doi:10.1504/IJIMA.2010.030434

Gregory, A. (2009). Etika i profesionalizam u odnosima s javnošću. In R. Tench \& L. Yeomans (Eds.), Otkrivanje odnosa s javnošću. Zagreb.

Ivanović-Đukić, I. (2011). Promovisanje društveno odgovornog poslovanja preduzeća u Srbiji. Sociologija, 53(1), 21-42.

Kassinis, G., \& Vafeas, N. (2006). Stakeholder pressures and environmental performance. Academy of Management Journal, 49, 145-159.

King, A., \& Lenox, M.J. (2002). Exploring the profitable pollution reduction. Management Science, 48, 289-299.

Kim, Y. (2014). Strategic communication of corporate social responsibility (CSR): Effects of stated motives and corporate reputation on stakeholder responses. Public Relations Review, 40(5), 838-840.

Lukić, (. (2010). Management of public relations in transition. In: International Scientific Conference MANAGEMENT, 2010.

Maignan, I., \& Ralston, D.A. (2002). Corporate social responsibility in Europe and the US: Insights from businesses' self-presentations. Journal of International Business Studies, 33(3), 497-514.

Makni, R.C., Francoeur, C., \& Ballavance, F. (2009). Causality between corporate social performance and financial performance: Evidence from Canadian firms. Journal of Business Ethics, 89, 409-422.

Mirosavljević, M. (2008). Odnosi s javnošću. Banja Luka college-besjeda Banja Luka. 
Vuković A. et al.: Corporate Social Responsibility as a part of Corporate Public ...

Porter, M.E., \& Kramer, M.R. (2007). The Link Between Competitive Advantage and Corporate Social Responsibility. Harvard business review,

Santini, I. (2007). Ugrožava li teorija interesno utjecajnih skupina primat koncepta maksimizacije vrijednosti kao cilja ponašanja firme. Ekonomski pregled, 58(5-6), 328-344.

Skoko, B., \& Mihovilović, M. (2014). Odnosi s javnošću u funkciji društveno odgovornog poslovanja. Praktični menadžment, stručni časopis za teoriju $i$ praksu menadžmenta, 5(1), 84-91.

Smith, K. T., Smith, L. M., \& Wang, K. (2010). Does brand management of corporate reputation translate into higher market value? Journal of Strategic Marketing, 18(3), 29-34.

Smith, K. T., \& Alexander, J. J. (2013). Which CSR-Related Headings Do Fortune 500 Companies Use on Their Websites?. Business Communication Quarterly, 76(2), 155-171.

Sommerville, I., (2007). Poslovna etika, odnosi s javnošću i korporativna društvena odgovornost. U:Theaker, A. (2007): Priručnik za odnose s javnošću. Zagreb

Tench, R., \& Yeomans, L. (2009). Otkrivanje odnosa s javnošću. Zagreb: Hrvatska udruga za odnose s javnošću.

Verboven, H. (2011). Communicating CSR and business identity in the chemical industry through mission slogans. Business Communication Quarterly, 74, 415431. 
